E3S Web of Conferences 1, 13004 (2013)

DOI: $10.1051 / \mathrm{e} 3$ sconf/20130113004

(c) Owned by the authors, published by EDP Sciences, 2013

\title{
Decontamination of Heavy Metals in Polluted Soil by Phytoremediation Using Bryophyllum Pinnatum
}

\author{
$\underline{\text { P. A. Ekwumemgbo }}^{1}$, N. O. Eddy ${ }^{2}$ and I. K. Omoniyi ${ }^{3}$ \\ ${ }^{1}$ Department of Chemistry, Ahmadu Bello University, Zaria, Kaduna State, NIGERIA, pat_adamma@yahoo.com \\ ${ }^{2}$ Department of Chemistry, Ahmadu Bello University, Zaria, Kaduna State, NIGERIA, nabukeddy@yahoo.com \\ ${ }^{3}$ Department of Chemistry, Ahmadu Bello University, Zaria, Kaduna State, NIGERIA, israelflourish@yahoo.com
}

\begin{abstract}
Phytoremediation is the use of specially selected or engineered living green plants for in situ risk reduction and/or removal of pollutants from contaminated media. This process is one of the most rapidly developing components of environmentally friendly (green) and cost-effective technology to abate environmental pollution. The risk reduction could be through the process of removal, degradation, containment of a contaminant or a combination of any of these factors. Bryophyllum pinnatum a herbally-accepted plant in some parts of the world was cultivated in ten different plastic buckets containing heavy metal polluted soil and nurtured for 20 months. The plants were left in ambient conditions and watered periodically. After the first 2 weeks, the plant and soil samples were collected and analysed for total concentration of $\mathrm{Cd}, \mathrm{Cr}, \mathrm{Cu}, \mathrm{Ni}, \mathrm{Pb} \mathrm{V}$ and $\mathrm{Zn}$. Subsequently, the plant and soil samples were collected monthly and analysed for the total concentrations of these heavy metals, using Atomic Absorption Spectrophotometry. Maximum extracted heavy metals from soil by plant were Cd $(3.12 \pm 1.03 \mathrm{mg} / \mathrm{kg}), \mathrm{Cr}(32.48 \pm 3.21 \mathrm{mg} / \mathrm{kg}), \mathrm{Cu}(81.01 \pm 2.3 \mathrm{mg} / \mathrm{kg}) \mathrm{Ni}$ $(11.91 \pm 2.32 \mathrm{mg} / \mathrm{kg}), \mathrm{Pb}(399.90 \pm 4.32 \mathrm{mg} / \mathrm{kg}) \mathrm{V}(5.81 \pm 0.08 \mathrm{mg} / \mathrm{kg})$ and $\mathrm{Zn}(150.51 \pm 0.33)$ and this occurred in the 4th month of study. This study confirms B. pinnatum as one of the plants that could be employed in phytoremediation of soil polluted by heavy metals.
\end{abstract}

Key words: Phytoremediation, heavy metals, soil, B. pinnatum, decontamination

\section{Introduction}

The global health impacts from toxic pollutants such as heavy metals are greater than previously thought. Today, over 100 million people are estimated to be at risk from heavy metal pollution at levels above international health standards. This is a public health issue as salient as tuberculosis, malaria, and HIV/AIDS, and one that should receive considerable attention and resources. Toxic pollution causes immense harm to humans, especially children. Health impacts include physical and mental disabilities, reduced IQ, organ dysfunction, neurological disorders, cancers, reduced life expectancy and in some cases, death. These pollutants exacerbate other health concerns by weakening the body's immune system, rendering it more susceptible to diseases. An initial exposure to toxic pollution can be the undocumented cause of later illnesses, including respiratory infections, tuberculosis, gastrointestinal disorders, and maternal health problems. In addition, while most toxic pollution is localized, some pollutants are trans-boundary and end up in food chains in oceans and distant countries (Blacksmith Institute's report, 2010).
Phytoremediation is a broad term that has been in use since 1991 to describe the use of plants to reduce the volume, mobility, or toxicity of contaminants in soil, groundwater, or other contaminated media (McCutcheon, 2003). Most heavy metals are phytotoxic at both low and high concentrations (Singh et al., 2011). Contaminated environment could be cleaned by phytoremediation technique. This is an emerging technology that offers more ecological benefits and a cost-efficient alternative (Mudgal et al., 2010). Knowledge of the physiological and molecular mechanisms of phytoremediation has begun to unfold together with biological and engineering strategies designed to optimise and improve the phytoremediation process (Schwitzguebel, 2000). Several plants have been identified in the last two decades as highly effective in absorbing and accumulating various toxic heavy metals. These are being evaluated for their role in the phytoremediation of polluted environment (Liao and Chang, 2004). Plant based technologies for metal decontamination is extraction, volatilization, stabilisation and rhizofiltration (Hooda, 2007).

The most vital factor in implementing phytoremediation is technical strategy, expert project 
designs with field experience for an excellent choice of the proper species and cultivars for particular metals and regions, and the selection of an appropriate plant which is often done by considering previous applications and research. The final plant choice is usually influenced by the situation of the site which affects the plant growth (Kutty et al., 2009). Several research has been carried out on phytoremediation, for instance Liao and Chang (2004) reported water hyacinth to be a promising candidate for phytoremediation of wastewater polluted with copper $(\mathrm{Cu})$, lead $(\mathrm{Pb})$, zinc $(\mathrm{Zn})$ and cadmium (Cd). Mojiri (2012) also carried out phytoremediation of heavy metals from municipal wastewater by Typhadomingensis.

The plant Bryophyllum pinnatum (Crassulaceae) depicted in Fig. 1 is commonly known as air plant, miracle leaf, life plant etc. It is accepted as a herbal remedy in some parts of the world, Nigeria inclusive. Many of its uses have been validated by animal studies and clinical investigations (Rossi-Bergmann, 2000; Igwe and Akunyili, 2005). This research investigated the efficiency of this plant as a metal hyperaccumulator for phytoremediation of heavy metal contaminated soil.

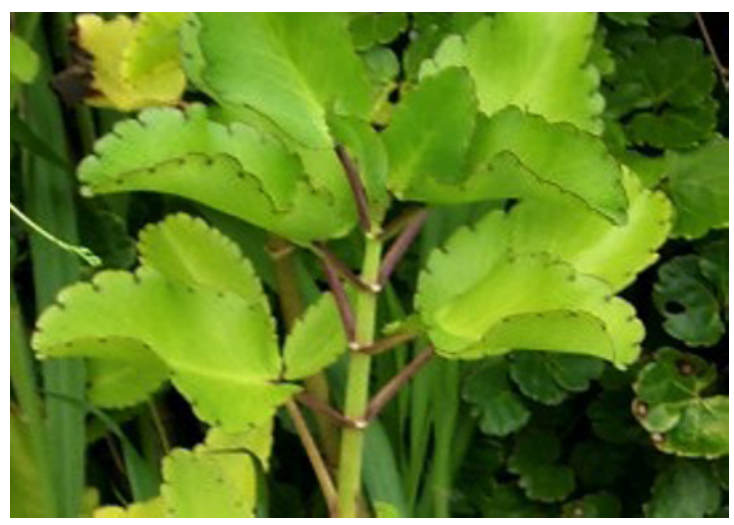

Fig. 1. Bryophyllum pinnatum plant.

It has been suggested that ideal plants for phytoremediation should possess properties such as fast growing, high biomass, deep roots, easy to harvest and should tolerate and accumulate a range of heavy metals in their aerial and harvestable parts (Grispen et al., 2006; Clemens et al., 2002). Hyperacumulator plants are able to tolerate high concentrations of toxic metals by producing molecules (phytochelatins) that bind metals into complexes that can be compartmentalized, thus preventing encroachment on sensitive plant tissues that may kill the plant (Dzantor, 2000).

\section{Materials and Methods}

Polluted soil samples were collected from an industrial layout in Kano State, Nigeria. Previous studies indicated that the soil was highly polluted with heavy metals. $B$. pinnatum was collected from the Botanical Garden in Ahmadu Bello University, Zaria in Nigeria. This study was carried out at greenhouse according to randomized complete block design with ten replications (Mojiri,
2012). Every B. pinnatum plant was cultivated in ten different plastic buckets containing heavy metals polluted soils and nurtured for 20 weeks. The plants were left in ambient conditions and watered periodically. After the first 2 weeks plant and soil samples were collected and analyzed for heavy metals content. Subsequently plant and soil samples were collected every four weeks for metal analyses, till the end of the twenty weeks (Odomelem and Ukpe, 2008).

The plant tissues and soil samples were prepared for laboratory analysis by wet digestion method in accordance to Standard Methods (APHA, 1998). Total concentrations of $\mathrm{Cd}, \mathrm{Cr}, \mathrm{Cu}, \mathrm{Ni}, \mathrm{Pb} \mathrm{V}$ and $\mathrm{Zn}$ in the prepared samples were determined by Basic Pye Unicam model 192 atomic absorption spectrophometer (AAS), equipped with automatic background correction, this was used to compensate for non-specific absorption and scattering of light. Standard addition method was used to check matrix interference. The result of each sample was the average of ten sequential readings.

\section{Results and Discussion}

Table 1 shows the concentration of metals absorbed periodically by $B$. pinnatum, and the concentration of metals in soil and the phytoextraction coefficient which is [metal in plant]/[metal in soil]. The amount of each heavy metal absorbed by $B$. pinnatum increased as the period of exposure to the heavy metal increased. Maximum amounts of the metals were absorbed in the 4th month of the study period. However, phytoextraction coefficients of all the metals investigated dropped in the 5 th month and the concentration of each metal absorbed by $B$. pinnatum also decreased. The duration of exposure to heavy metals is a major factor affecting bioaccumulation of heavy metals in plants. On the other hand, factors affecting the level of heavy metals in the soil include soil $\mathrm{pH}$, solubility of the metal in soil solution, the organic matter content, cation exchange capacity and the oxidation state of the metal. This result is in agreement with the result obtained by Odomelem and Ukpe (2008) who worked on a landfill in a batteries industry in Nigeria.

As depicted in Fig. 2 which is the plot of phytoextraction coefficient versus time. The shape of the curve shows that, there is a time lag before considerable amounts of the metals could be bioaccumulated in the plant. This indicates that the plant needed some time to adjust its internal structures to accumulate high levels of the metals. On the basis of phytoextraction coefficient, within the first two weeks, Ni was the highest absorbed metal followed by $\mathrm{Cr}$ while $\mathrm{Cd}$ was the least absorbed. At maximum bioaccumulation of metals the concentration of metals followed the order: $\mathrm{Cu}>\mathrm{Zn}>\mathrm{Pb}>\mathrm{Ni}>\mathrm{Cd}>\mathrm{V}>$ Cr.

Fig. 3 depicts an overview of a typical phytoremediation process. The mechanism of phytoremediation process stems from the fact that plants in conjunction with bacteria and fungi in the rhizosphere (narrow region of soil that is directly influenced by root secretions and associated soil microorganism) transform, 
Table1. Concentration (mg/kg) of heavy metals absorbed by Bryophyllum pinnatum

\begin{tabular}{lllllll}
\hline Period & & Ni & Pb & Cr & V & Cd \\
\hline \multirow{3}{*}{$1 / 2$ Month } & P & $3.02 \pm 0.01$ & $4.11 \pm 0.06$ & $4.76 \pm 0.03$ & $0.09 \pm 0.001$ & $0.08 \pm 0.02$ \\
& S & $10.69 \pm 0.01$ & $38.72 \pm 2.30$ & $30.57 \pm 1.23$ & $3.52 \pm 1.22$ & $3.14 \pm 1.02$ \\
& C & $0.28 \pm 0.10$ & $0.106 \pm 0.01$ & $0.16 \pm 0.01$ & $0.03 \pm 0.001$ & $0.03 \pm 0.001$ \\
1 Month & P & $3.72 \pm 0.01$ & $4.19 \pm 0.05$ & $5.68 \pm 2.00$ & $1.09 \pm 0.02$ & $0.12 \pm 0.002$ \\
& S & $92.10 \pm 1.36$ & $48.01 \pm 0.06$ & $23.67 \pm 1.23$ & $12.31 \pm 1.02$ & $4.31 \pm 0.81$ \\
& C & $0.31 \pm 0.01$ & $0.09 \pm 0.00$ & $0.24 \pm 0.01$ & $0.09 \pm 0.002$ & $0.03 \pm 0.011$ \\
2 Months & P & $3.91 \pm 0.10$ & $30.08 \pm 3.42$ & $9.17 \pm 1.12$ & $4.17 \pm 1.07$ & $0.05 \pm 0.002$ \\
& S & $10.81 \pm 1.00$ & $420.07 \pm 5.23$ & $14.61 \pm 1.56$ & $10.10 \pm 2.01$ & $4.01 \pm 0.01$ \\
& $\mathrm{C}$ & $0.36 \pm 0.02$ & $0.07 \pm 0.01$ & $0.63 \pm 0.01$ & $0.41 \pm 0.01$ & $0.01 \pm 0.001$ \\
3 Months & $\mathrm{P}$ & $6.82 \pm 0.02$ & $28.10 \pm 1.26$ & $9.83 \pm 0.98$ & $5.29 \pm 1.02$ & $2.31 \pm 1.02$ \\
& $\mathrm{~S}$ & $10.10 \pm 1.05$ & $310.14 \pm 3.42$ & $14.89 \pm 2.02$ & $10.47 \pm 2.03$ & $3.21 \pm 1.01$ \\
& $\mathrm{C}$ & $0.68 \pm 0.02$ & $0.91 \pm 0.01$ & $0.66 \pm 0.01$ & $0.51 \pm 0.02$ & $0.72 \pm 0.002$ \\
4 Months & $\mathrm{P}$ & $11.91 \pm 2.32$ & $399.90 \pm 4.32$ & $32.48 \pm 3.21$ & $5.81 \pm 0.08$ & $3.12 \pm 1.03$ \\
& $\mathrm{~S}$ & $9.90 \pm 1.36$ & $306.70 \pm 5.33$ & $45.84 \pm 3.11$ & $8.03 \pm 0.09$ & $3.01 \pm 0.01$ \\
& $\mathrm{C}$ & $1.20 \pm 0.01$ & $1.30 \pm 0.01$ & $0.71 \pm 0.02$ & $0.72 \pm 0.02$ & $1.04 \pm 0.41$ \\
5 Months & $\mathrm{P}$ & $10.24 \pm 2.45$ & $223.40 \pm 4.53$ & $5.93 \pm 1.56$ & $4.23 \pm 1.08$ & $2.08 \pm 0.14$ \\
& $\mathrm{~S}$ & $10.27 \pm 3.27$ & $356.10 \pm 6.22$ & $43.59 \pm 1.88$ & $7.00 \pm 0.12$ & $3.40 \pm 1.30$ \\
& $\mathrm{C}$ & $1.00 \pm 0.01$ & $0.63 \pm 0.01$ & $0.14 \pm 0.001$ & $0.605 \pm 0.11$ & $0.61 \pm 0.002$ \\
\hline
\end{tabular}

$\mathrm{Y}=$ Initial concentrations of heavy metals.

$\mathrm{P}=$ Concentration of metal in B. pinnatum at the relevant time interval.

$\mathrm{S}=$ Concentration of metal in soil at the relevant time interval.

$\mathrm{C}=$ Phytoextraction coefficient.

transport or store harmful chemicals. Plants attributes make them good candidates for bioaccumulation of heavy metals. The mechanism of phytoremediation process is as follows: root system surface areas absorb substances and accumulate water, nutrients and minerals; there is selective take up of metals; development of diversity and adaptability to tolerate high levels of metals and other pollutants; uptake of pollutants by plants and transformation in plant tissue to a less toxic form Phytotransformation/Phytodegradation); trees transpire large quantities of water so pumping action prevent contaminants from migration into the water table (Phytostabilisation). Phytodegradation and stabilisation are enhanced by soil aeration, plant exudates soil microbiota stimulated by plant exudates. The use of the extensive root system of plants as a filter (Rhizofiltration); gradual aaccumulation and subsequent hyperaccumulation of metals in above-ground tissues for harvest (Phytoextraction); and root systems in the plant holds contaminated soils in place and prevent mechanical transportation of pollutants from wind and erosion.

\section{Conclusion}

At present, phytoextraction is one of the best-developed toxic metal phytoremediation nearing commercialization. Although major opportunities for the phytostabilization of toxic metals also exist, this technology is relatively less developed than those described above. This situation should improve as more researchers become interested in this area. Short-term advances in phytoextraction are likely to come from the development of effective chemical soil amendments and efficient ways of applying them. In addition, the ability of plants to accumulate toxic metals in their shoots may be enhanced through the use of specific chemicals (mainly metal-chelating agents) that facilitate the acquisition and transport of metals. Major long-term improvements in phytoremediation should come when scientists isolate genes from various plants, bacterial and animal sources that can enhance the metalaccumulating potential of the plants in which these genes are inserted.

\section{References}

Adhikari T, Manna MC, Singh MV, Wanjari RH. Bioremediation measure to minimize heavy metals accumulation in soils and crops irrigated with city effluent. Food, Agriculture \& Environment 2004; 2(1): $266-270$.

Blacksmith Institute's report. World's Worst Pollution Problems Report Top Six Toxic Threats. Produced in collaboration with Green Cross Switzerland 2010; p.76

Clemence S, Palmgren MG, Kramer U. A long way ahead: Understanding and engineering plant metal 


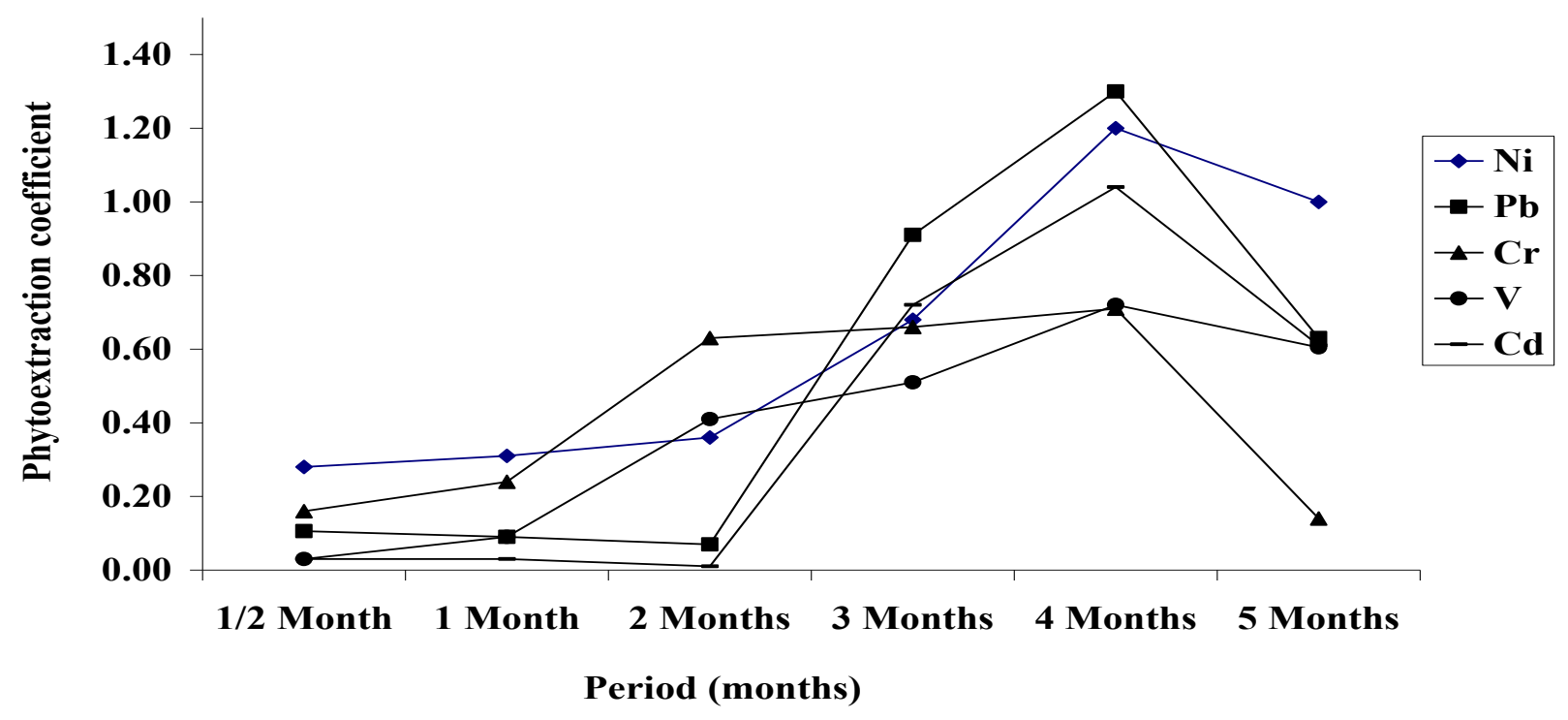

Fig. 2. Plot of phytoextraction coefficient versus time

accumulation. Trends in Plant Science 2002; 7: $309-$ 315.

Dzantor EK. Phytoremediation - Plant based strategies for cleaning up contaminated soils - Metal contaminants. Maryland Cooperative Extension, University of Maryland, College Park 2000; p. 768.

Eddy NO, Ekop AS. Phytoremediation potentials of some Nigerian weeds. Asian Journal of chemistry 2007; 19(3): 1825 - 1831. Ghasi S, Egwuibe C, Achukwu PU, Onyeanusi JC. Assessment of the medical benefit in the folkloric use of Bryophyllum Pinnatum leaf among the Igbos of Nigeria for the treatment of hypertension African Journal of Pharmacy and Pharmacology 2011; 5(1): 83 - 92 .

Ghosh M, Singh SP. A comparative study of cadmium phytoextraction by accumulator and weed species. environmental Pollution 2005; 133: 365 - 371.

Grispen VMJ, Nelissen HJM, Verkleij JAC. Phytoextration with Brassica napus L.: A tool for sustainable management of heavy metal contaminated soils. Environmental Pollution 2006; 144: $77-83$.

Igwe SA, Akunyili DN. Analgesic Effects of Aqueous extracts of the leaves of B. Pinnatum. Pharmaceutical Biolology 2005; 43(8): 658-661.

Obot N. Sporonulus pyramidalis as a bioindicator for heavy metal pollution. M.Sc. Thesis, University of Uyo, Nigeria 2006.

Raskin I, Ensley BD. Phytoremediation of Toxic Metals: Using Plants to Clean up the Environment. Wiley, New York 2000.

Salt DE, Smith RD. Raskin L. Phytoremediation. Annual Review of Plant Physiology and Plant Molecular Biology 1998; 49: 643-668.

Rossi-Bergmman B. Treatment of Cutaneous leishmaniasis with B. pinnatum: experimental and clinical data. Phytomedicine. suppl., 2000; 7(2): $115-117$.

Vidali M. Bioremediation: An overview. Pure Applied Chemistry 2001; 73(7): $1163-1172$. 